\title{
THE EFFECT OF ONE SESSION OF SUPRAGINGIVAL PLAQUE CONTROL ON CLINICAL AND BIOCHEMICAL PARAMETERS OF CHRONIC PERIODONTITIS
}

\author{
EFEITO DE UMA ÚNICA SESSÃO DE CONTROLE DE PLACA SUPRAGENGIVAL NOS \\ PARÂMETROS CLÍNICOS E BIOQUÍMICOS DA PERIODONTITE CRÔNICA
}

\author{
Érica Del Peloso RIBEIROํㅗㅇ, Sandro BITTENCOURT ${ }^{1}$, Francisco Humberto NOCITI-JÚNIOR², \\ Enilson A. SALLUM ${ }^{3}$, Antonio W. SALLUM ${ }^{3}$, Márcio Zaffalon CASATI ${ }^{3}$
}

\begin{abstract}
1- DDS, MSc, PhD, Graduate student (Doctor degree) Department of Prosthodontics and Periodontics, School of Dentistry at Piracicaba, University of Campinas.

2- DDS, MSc, PhD, Associate Professor Department of Prosthodontics and Periodontics, School of Dentistry at Piracicaba, University of Campinas.

3- DDS, MSc, PhD , Associate Professor Department of Prosthodontics and Periodontics, School of Dentistry at Piracicaba, University of Campinas.

Corresponding address: Érica Del Peloso Ribeiro - Rua Luis Rasera n. 300, apt. 21, Bloco Del Romano - Jardim Elite - Cep.: 13417-530 Piracicaba-SP - Phone: 19-3411-6327/ 19-8134-6966 - e-mail: ericapeloso@fop.unicamp.br
\end{abstract}

Received: March 16, 2004 - Modification: December 09, 2004 - Accepted: March 11, 2005

\begin{abstract}
S

$\mathcal{S}$ upragingival plaque control is a requisite for the success of any periodontal procedure. However, little is know about the effect of this procedure alone on periodontitis. The aim of this study was to determine the effect of supragingival plaque control on clinical and biochemical parameters of chronic periodontitis. Twenty-five subjects exhibiting at least 4 pockets $\geq$ $5 \mathrm{~mm}$, non-smokers and with no relevant systemic diseases, were selected for the study. The clinical and biochemical assessments were done before and 21 days after removal of plaque retentive factors, extraction of affected teeth and instruction in oral hygiene. The statistical analysis was done with the Student paired t-test $(\mathrm{p}<0,05)$ and demonstrated a reduction on the percentage of sites with bleeding on probing from $42.72 \pm 15.83$ to $35.87 \pm 13.30(\mathrm{p}=0.002)$. Reduction in probing depth was detected on anterior teeth (initial/final mean: $2.88 \mathrm{~mm} / 2.78 \mathrm{~mm}$; $\mathrm{p}=0.01$ ) and interproximal sites (initial/final mean: $3.80 \mathrm{~mm} / 3.65$ $\mathrm{mm} ; \mathrm{p}=0.001$ ). There was an increase from $66.81 \%$ to $68.65 \%$ in the number of sites with probing depth of 1 to $3 \mathrm{~mm}$ and a decrease from $26.21 \%$ to $24.17 \%$ in those with probing depth of 4 to $6 \mathrm{~mm}$. The BAPNA results showed a decrease from 51.44 \pm 20.78 to $38.64 \pm 12.34(\mathrm{p}=0.04)$. This study demonstrated that supragingival plaque control provides a reduction in gingival inflammation and alterations in the subgingival microflora detected by the BAPNA test.

Uniterms: Supragingival plaque, control; Subgingival microflora; Periodontitis.
\end{abstract}

\footnotetext{
RESUMO

$O$

objetivo deste estudo foi avaliar o efeito do controle de placa supragengival sobre os parâmetros clínicos e bioquímicos da periodontite crônica. Foram selecionados 25 pacientes apresentando pelo menos 4 sítios com profundidade de sondagem $\geq 5$ mm, não fumantes e sem alterações sistêmicas relevantes. A avaliação clínica e bioquímica foi feita antes e 21 dias após a remoção dos fatores retentivos de placa, exodontia dos dentes condenados e instrução de higiene bucal. A análise estatística foi feita através do teste $t$ de Student pareado $(\mathrm{p}<0,05)$ e demonstrou redução da porcentagem de sítios com sangramento à sondagem de 42,72 $\pm 15,83$ para 35,87 $\pm 13,30$ ( $p=0,002$ ). Redução na profundidade de sondagem foi observada nos dentes anteriores (média inicial/final: 2,88 mm/2,78 mm; p=0,01) e faces interproximais (média inicial/final: 3,80 mm/3,65 mm; p=0,001). Houve aumento de 66,81\% para 68,65\% (p=0,03) no número de sítios com profundidade de sondagem de 1 a 3 mm e redução de 26,21\% para 24,17\% (p=0,04) nos de 4 a 6 mm. O valor do BAPNA apresentou redução de 51,44 $\pm 20,78$ para 38,64 $\pm 12,34$ $(\mathrm{p}=0,04)$. Baseado nesses achados pôde-se concluir que o controle de placa supragengival tem efeitos benéficos, principalmente relacionados à redução da inflamação gengival e da atividade de enzima tipo tripsina no biofilme subgengival (BAPNA). Unitermos: Placa supragengival, controle; Microbiota subgengival; Periodontite.
} 


\section{INTRODUCTION}

The primary etiological factor of periodontal disease is bacterial plaque ${ }^{15}$. Based on this knowledge, periodontal therapy is directed toward the elimination of bacterial plaque with instruction in oral hygiene and scaling and root planing performed with or without surgical access.

Clinical studies have demonstrated the effectiveness of this combined approach on the treatment of periodontal disease $\mathrm{s}^{3,23}$. The reduction in probing pocket depth and gain in clinical attachment is related to a reduction in the quantity of subgingival bacteria and an alteration in the composition of subgingival microbiota ${ }^{7}$.

Nevertheless, some studies do not report significant microbial improvements after subgingival debridement, possibly because of insufficient oral hygiene follow-up ${ }^{18,23}$. This information shows the importance of an adequate plaque control as a requisite for the success of any periodontal procedure.

In view of the established importance of supragingival plaque control in traditional periodontal therapy, it is surprising that until recently so little attention has been devoted to the influence of supragingival plaque control alone on periodontitis ${ }^{14}$. Thus, the relevant clinical findings are for the most part derived from control segments in a variety of different investigations ${ }^{3,21}$.

Different opinions are available concerning the clinical and microbiological effects of supragingival plaque control alone on untreated periodontitis patients. The knowledge of this effect would be important to take advantage of the supragingival plaque control in the diagnostic and treatment of periodontal disease and also to better understand the relationship between supra and subgingival plaque.

The influence of supragingival plaque control on the composition of subgingival microflora was confirmed in an animal model and by other clinical studies ${ }^{8,22,23}$. However, other studies were not able to endorse the observations of markedly favourable effects of supragingival cleaning on the subgingival microbiota ${ }^{4,13}$.

The effect of supragingival plaque control alone in clinical parameters of periodontitis has been investigated and some studies show little or no change on probing depth $^{4,17}$. Others studies show changes of approximately $1 \mathrm{~mm}^{11,13}$. A series of factors such as initial probing depth, category of the site (suprabony, infrabony or furcating pockets) and level of plaque control affect the measurement of probing depth and may be responsible for the disagreement between studies ${ }^{11,14}$.

The review of existing literature on this topic indicates the importance of supragingival plaque control on periodontitis and the necessity of studies regarding the effects of different protocols of supragingival plaque control. Thus, the aim of the present investigation was to study the clinical and biochemical effects of one session of professional supragingival plaque removal and oral hygiene instructions on chronic periodontitis.

\section{MATERIALAND METHODS}

Twenty-five patients, 22-60 years of age, were selected from the pool of patients referred for treatment to the Department of Periodontology in Piracicaba Dental School, University of Campinas-Brazil.

All subjects had, on the basis of clinical and radiographic evidence, chronic periodontitis and a minimum of 4 pockets with probing depth $\geq 5 \mathrm{~mm}$ and loss of clinical attachment $\geq$ $5 \mathrm{~mm}$. They had not received any antibiotic or periodontal treatment in the 6 months preceding the start of the study. The subjects were non-smokers and had no history of any systemic disease suspected to contribute to periodontal disease.

Respecting the study protocol approved by the Ethics Committee of the institution, the patients signed an informed written consent for participation in the study (Resolution $\mathrm{n}^{\circ} 196$ from the National Health Council, Health Ministry, Brasilia, 03/10/1996).

Clinical and biochemical assessment were performed before and 21 days after the supragingival plaque control, removal of plaque retentive factors, extraction of condemned teeth and instruction in oral hygiene. Only one operator performed the treatment.

The supragingival calculus was removed with an ultrasonic device and the excess of restorations with a diamond bur. The extracted teeth were not included in the baseline assessments. The patients were instructed to brush their teeth according to the Bass technique and received additional instructions for proper interdental cleaning with dental floss. After conclusion of the study all periodontal pockets received subgingival instrumentation.

The clinical parameters studied were: plaque index ${ }^{1}$; bleeding on probing ${ }^{19}$; probing pocket depth and clinical attachment level. The clinician performing the clinical measurements was calibrated. The Kappa values for probing pocket depth and clinical attachment level were 0.89 . These measurements were done on all teeth, at 6 locations per tooth to nearest $1 \mathrm{~mm}$ using a standardized periodontal probe (PCPUNC 15âHu-Friedy, Chicago, IL, USA).

The biochemical evaluation was done with the BAPNA test that permits the detection of microorganisms possessing trypsin-like enzymes such as $T$. forsythensis, Treponema denticola and $P$. gingivalis. Subgingival dental plaque was collected from sites with probing depth $\geq 5 \mathrm{~mm}$. Before sampling, the area was dried, isolated and had the supragingival plaque removed with sterilized Gracey curettes (Hu-Friedy, Chicago, IL, USA).

The plaque collected was placed in preweighed coded microcentrifuge tubes. An amount of $1 \mathrm{ml}$ of a solution containing the enzyme substrate (N-benzoyl-L-arginine-pnitroanilide, BAPNA; Sigma, St. Louis, Missouri, USA) was added to the tubes. This suspension was vortexed and then placed in an ultrasound bath on ice for $10 \mathrm{~min}$ with 2-second cycles and 2-second intervals at $17 \mathrm{~W}$ using a $100 \mathrm{~W}$ ultrasonic processor. After $17 \mathrm{~h}$ of incubation at $37^{\circ} \mathrm{C}$, the reaction was stopped with ice and by the addition of $100 \mathrm{ml}$ of glacial acetic acid. The absorbance was read at $405 \mathrm{~nm}^{27}$. 
The results were given in nanomoles of product per minute per milligram of dental plaque wet weight.

The Student paired t-test was used to analyze differences between mean values for the clinical parameters at the baseline and 21-day examinations. The biochemical parameter was analyzed with the Wilcoxon test at the same interval. Patient means rather than site means were used.

\section{RESULTS}

The 25 patients had a mean age of 47.12 years ( 9 males; 16 females). The baseline characteristics are presented in presented in Table 1 . They showed, in general, poor compliance with plaque control. The initial value of plaque index was $47.42 \% \pm 21.09$ and 21 days after the initiation of supragingival plaque control it was $48.52 \% \pm 19.14$. However, difference in the percentage of sites with bleeding on probing was observed. The initial value was $42.72 \% \pm 15.83$ and 21 days after the initiation of supragingival plaque control it was $35.86 \% \pm 13.30(\mathrm{p}=0.002)$.

The probing pocket depth before and after the supragingival plaque control was $3.39 \mathrm{~mm}$ and $3.30 \mathrm{~mm}$ $(p=0.02)$, respectively. The probing pocket depth was analyzed separately for anterior and posterior teeth; interproximal and non-interproximal sites. The initial probing depth was higher in posterior teeth when compared to anterior teeth and higher in interproximal sites when compared to non-interproximal ones. A significant reduction

TABLE 1- Baseline means (+ standard deviation-SD) of age, gender, clinical and biochemical parameters

\begin{tabular}{ll}
\hline CHARACTERISTICS & $\begin{array}{c}\text { STUDY SAMPLE } \\
\text { (25 PATIENTS) }\end{array}$ \\
\hline AGE (range) & $22-60$ years \\
$\%$ MEN & 36 \\
BOP (\%) & $42.72(15.83)$ \\
PPD (mm) & $3.39(0.61)$ \\
CAL $(\mathrm{mm})$ & $3.93(0.99)$ \\
BAPNA & $51.44(20.78)$ \\
\hline
\end{tabular}

in the probing depth of the anterior teeth and interproximal sites was observed (Table 2).

The initial gingival recession was $0.63 \mathrm{~mm}$ and at the end of the study it was $0.65 \mathrm{~mm}$. The change in clinical attachment, from $3.93 \mathrm{~mm}$ in the beginning of the study to $3.89 \mathrm{~mm}$ at the end, was also not significant. This parameter was also analyzed for anterior and posterior teeth; interproximal and non-interproximal sites (Table 2).

After the supragingival plaque control program was initiated there was a significant increase in the number of sites with a probing depth between 1 and $3 \mathrm{~mm}$. This was associated with a reduction in the number of sites with a probing depth of 4 to $6 \mathrm{~mm}$. The number of sites with probing depth $\geq 7 \mathrm{~mm}$ remained practically the same (Table 3 ). Both probing pocket depth and clinical attachment changes were evaluated separately in sites with probing depth of 1 to 3 $\mathrm{mm}, 4$ to $6 \mathrm{~mm}$ and $\geq 7 \mathrm{~mm}$ (Table 4 ).

The biochemical assessment showed a significant reduction in the values of BAPNA that were before the supragingival plaque control 51.44 \pm 20.78 and after 38.64 \pm $12.34(\mathrm{p}=0.02)$.

\section{DISCUSSION}

The aim of the present investigation was to study to what extent clinical improvements are achievable in untreated periodontitis with only one session of supragingival plaque control, and if so, whether these clinical changes would be mirrored by biochemical changes in the subgingival microflora.

TABLE 3- Percentage of sites in the three categories of probing pocket depth (PPD) before and 21 days after the beginning of supragingival plaque control

\begin{tabular}{lll}
\hline PPD & Before & After \\
\hline 1 to $3 \mathrm{~mm}$ & $66.81^{\mathrm{a}}$ & $68.65^{\mathrm{b}}$ \\
4 to $6 \mathrm{~mm}$ & $26.21^{\mathrm{c}}$ & $24.17^{\mathrm{d}}$ \\
$\geq 7 \mathrm{~mm}$ & $6.97^{\mathrm{e}}$ & $7.18^{\mathrm{e}}$ \\
\hline
\end{tabular}

* different letters indicate statistically significant difference $(P<0.05)$ detected with the paired t test.

TABLE 2- Mean probing pocket depth - PPD and clinical attachment level - CAL ( $\mathrm{mm}$ ) of anterior and posterior teeth and of interproximal and non-interproximal sites before and 21 days after the beginning of supragingival plaque control

\begin{tabular}{lcccc}
\hline TOOTH-SITES & \multicolumn{2}{c}{ PPD } & \multicolumn{2}{c}{ CAL } \\
& BEFORE & AFTER & BEFORE & AFTER \\
\hline ANTERIOR & $2.88+0.71^{\mathrm{a}}$ & $2.78+0.75^{\mathrm{b}}$ & $3.61+1.20^{\mathrm{a}}$ & $3.51+1.22^{\mathrm{b}}$ \\
POSTERIOR & $3.77+0.67^{\mathrm{c}}$ & $3.68+0.62^{\mathrm{c}}$ & $4.34+0.78^{\mathrm{c}}$ & $4.28+0.73^{\mathrm{c}}$ \\
NON-INTERPROXIMAL & $2.54+0.50^{\mathrm{d}}$ & $2.57+0.48^{\mathrm{d}}$ & $3.46+0.96^{\mathrm{d}}$ & $3.53+0.96^{\mathrm{d}}$ \\
INTERPROXIMAL & $3.80+0.77^{\mathrm{e}}$ & $3.65+0.74^{\mathrm{f}}$ & $4.28+0.95^{\mathrm{e}}$ & $4.13+0.91^{\dagger}$ \\
ALL SITES & $3.39 \pm 0.67^{\mathrm{a}}$ & $3.30 \pm 0.70^{\mathrm{h}}$ & $3.93 \pm 1.03^{\mathrm{g}}$ & $3.89 \pm 1.02^{\mathrm{g}}$ \\
\hline
\end{tabular}

* different letters indicate statistically significant difference $(P<0.05)$ detected with the paired test. 
This study is in accordance with Al-Yahfoufi, et al. ${ }^{2}$ and Joli, et al. ${ }^{12}$ showing reduction in gingival inflammation. The reduction observed in probing pocket depth in this study was statistically significant. The studies of Beltrami, Bickel and Baehni ${ }^{4}$ and McNabb, Mombelli and Lang ${ }^{17}$ although have not reported changes in probing pocket depth with supragingival plaque control alone.

The discrepancy between the studies can be explained in accordance with Hellström, et al. ${ }^{11}$, by different types of pocket. These authors compared the effect of supragingival plaque control (2-3 times per week) on suprabony, infrabony and furcation pockets. After 30 weeks, there was a reduction in the probing depth of suprabony and furcations pockets. However, this was not true for the infrabony pockets.

The distinct protocols of supragingival plaque control and the level of compliance with oral hygiene instruction could also explain the discrepancy between studies. Loss, Claffey, Crigger ${ }^{16}$ established and monitored oral hygiene procedures in 15 patients with severe periodontitis. After 12 weeks, it was observed that those patients who better complied with the oral hygiene instructions showed more improvements in gingival conditions and greater reduction in probing pocket depth when compared to the ones who were less compliant.

In the present study, the removal of plaque retentive factors and oral hygiene instruction was carried out in one session. The plaque control during the next 21 days was a responsibility of the patient. This can explain the observation of no difference in plaque index. However, differences were observed in bleeding on probing that is an easy and appropriate method to evaluate the patient control of plaque $^{24}$.

The protocol of one session of supragingival plaque control was chosen because of the difficulty in making patients return 3 times per week for professional plaque control. But probably, better results could be obtained if during the 21 days, the patients returned 1 or 2 times for reinforcement of oral hygiene instructions and professional control of supragingival plaque.

The comparison between anterior and posterior teeth showed that in the beginning of the study the posterior ones presented greater probing pocket depth $(3.77 \mathrm{~mm} \mathrm{x}$ $2.88 \mathrm{~mm}$ ). The difficulty in cleaning the posterior teeth could explain these data ${ }^{5,12}$. This could also explain why the reduction in probing depth was statistically significant only in the anterior teeth.

The same comparison between interproximal and non- interproximal sites showed that in the beginning of the study the interproximal sites had a higher probing depth $(3.80 \mathrm{~mm}$ x $2.54 \mathrm{~mm}$ ). Significant reduction in the probing pocket depth was detected on the interproximal sites, probably because patients started to use dental floss, which until then was not used or was used improperly ${ }^{8,12}$.

The probing pocket depth was divided into 3 categories. The number of sites with probing depth from 1 to $3 \mathrm{~mm}$ increased and the number of sites from 4 to $6 \mathrm{~mm}$ decreased. This observation agrees with the studies of Dahlén, et al. ${ }^{8}$ and Sato, et al. ${ }^{21}$.

Influence of the supragingival plaque control in the position of gingival margin was not observed. On the other hand, Cercek, et al. ${ }^{6}$ and Badersten, Nilvéus, Egelberg ${ }^{3}$ demonstrated approximately $0.5 \mathrm{~mm}$ of gingival recession as consequence of supragingival plaque control. These studies had the mean probing pocket depth above $4 \mathrm{~mm}$. It is known that the occurrence of gingival recession is more pronounced in deeper pockets ${ }^{11,16}$.

In this study, since the occurrence of gingival recession was not observed, the reduction in the probing pocket depth is related to a gain in clinical attachment level. This was observed in anterior teeth and interproximal sites. The reduction in the probing pocket depth gain could also be explained by the reduction in gingival inflammation ${ }^{25}$. Fowler, et al. ${ }^{9}$ observed higher penetration of the periodontal probe in the junctional epithelium of untreated teeth when compared with periodontally treated teeth.

The influence of supragingival plaque control on the subgingival microflora is controversial. Siegrist and Kornman ${ }^{22}$ induced periodontal breakdown in monkeys to investigate the influence of improved supragingival plaque control alone on existing subgingival plaque. Changes in the periodontitis associated subgingival microflora occurred after six weeks. These alterations were not sufficient to alter clinical signs of disease.

The influence of supragingival plaque control alone on existing subgingival plaque has been endorsed by the observations of Smulow, Turesky, Hill ${ }^{23}$, McNabb, Mombelli, Lang $^{17}$, Dahlén, et al. ${ }^{8}$, although not by others ${ }^{4,13,16}$. Gomes and Marcantonio ${ }^{10}$ emphasized that Kho, Smales and Hardie $^{13}$, Beltrami, Bickel and Baehni ${ }^{4}$ did not observe reduction in inflammation and this could explain why they did not observe influence of supragingival plaque control on subgingival microflora. Ramberg, et al. ${ }^{20}$ showed that the formation of subgingival plaque is influenced by marginal edema.

TABLE 4- Probing pocket depth (PPD) and clinical attachment level (CAL), in $\mathrm{mm}$, before and 21 days after the beginning of supragingival plaque control in the three categories of probing depth

\begin{tabular}{|c|c|c|c|c|}
\hline \multirow[t]{2}{*}{ PPD } & \multicolumn{2}{|c|}{ PPD } & \multicolumn{2}{|c|}{ CAL } \\
\hline & Before & After & Before & After \\
\hline 1 a $3 \mathrm{~mm}$ & $2.30+0.19$ & $2.26+0.20$ & $2.44+0.21^{*}$ & $2.38+0.20 *$ \\
\hline 4 a $6 \mathrm{~mm}$ & $4.68+0.21$ & $4.69+0.22$ & $4.76+0.20$ & $4.76+0.19$ \\
\hline$\geq 7 \mathrm{~mm}$ & $7.47+0.34$ & $6.79+2.62$ & $8.09+0.81$ & $7.71+1.79$ \\
\hline
\end{tabular}

* indicates statistically significant difference $(P<0.05)$ detected with the paired test. 
In the present study supragingival plaque control, removal of plaque retentive factors, extraction of affected teeth and instruction in oral hygiene caused enzymatic changes in subgingival environment that were detected with the BAPNA test.

It has been suggested that the occurrence of gingival recession explains the alteration in the microbiota ${ }^{11}$. In the present study, however, the effect of supragingival plaque control on subgingival microbiota occurred and gingival recession was not observed. Hellström, et al. ${ }^{11}$ also showed a reduction in the total viable microorganisms counts as well as in the percentage of P. gingivalis in sites with no reduction in probing pocket depth.

Although the studies ${ }^{2,5,8,11,12}$ show, in different levels, beneficial effects of supragingival plaque control, it should not be used as the only treatment for chronic periodontitis. Westfelt, et al. ${ }^{26}$ reported that probing attachment loss $\geq$ $2 \mathrm{~mm}$ was more than $4 \mathrm{x}$ greater in the group receiving only oral hygiene instructions and supragingival scaling for 3 years when compared to the group that received also subgingival therapy.

\section{CONCLUSION}

Within the limits of the present study, it can be concluded that one session of supragingival plaque control provides a reduction in gingival inflammation and alterations in the subgingival microflora detected by the BAPNA test.

\section{REFERENCES}

1- Ainamo J, Bay I. Problems and proposals for recording gingivitis and plaque. Int Dent J. 1975;25:229-35.

2- Al-Yahfoufi Z, Mombelli A, Wicki A, Lang NP. The effect of plaque control in subjects with shallow pockets and high prevalence of periodontal pathogens. J Clin Periodontol. 1995;22:78-84.

3- Badersten A, Nilvéus R, Egelberg J. Effect of non-surgical periodontal therapy. II. Severely advanced periodontitis. J Clin Periodontol. 1984;8:63-76.

4- Beltrami M, Bickel M, Baehni PC. The effect of supragingival plaque control on the composition of the subgingival microflora in human periodontitis. J Clin Periodontol. 1987;4:161-4.

5- Catão VV, Chapper A, Oppermann RV. O efeito do controle de placa supragengival no diagnóstico da doença periodontal. Periodontia. 2001;11:44.

6- Cercek JF, Kiger RD, Garret S, Egelberg J. Relative effects of plaque control and instrumentation on the clinical parameters of human periodontal disease. J Clin Periodontol. 1983;10:46-56.

7- Cobb CM. Non-surgical pocket therapy: mechanical. Ann Periodontol. 1996;1:443-90.

8- Dahlén G, Lindhe J, Sato K, Hanamura H, Okamoto H. The effect of supragingival plaque control on the subgingival microbiota in subjects with periodontal disease. J Clin Periodontol. 1992;19:802 9 .
9- Fowler C, Garrett S, Crigger M, Egelberg J. Histologic probe position in treated and untreated human periodontal tissues. J Clin Periodontol. 1982;9:373-85.

10- Gomes SCG, Marcantonio RAC. Efeito do controle de placa bacteriana supragengival sobre indicadores clínicos e microbiológicos subgengivais: revisão de literatura. Periodontia. 2004;14:45-52.

11- Hellstrom M-K, Ramberg P, Krok L, Lindhe J. The effect of supragingival plaque control on the subgingival microflora in human periodontitis. J Clin Periodontol. 1996;23:934-40.

12- Joli JC, Obici LL, Lima A FM, Nociti FH. Avaliação dos parâmetros clínicos na elaboração do plano de tratamento periodontal. Periodontia. 1997;6:48-51.

13- Kho P, Smales FC, Hardie JM. The effect of supragingival plaque control on the subgingival microflora. J Clin Periodontol. 1985; $12: 676-86$.

14- Kieser JB. Non-surgical periodontal therapy. In: Lang NP, Karring T. Proceedings of the 1st European Workshop on Periodontology. London: Quintessence; 1994. p. 131-58.

15- Löe H, Theilade E, Jensen SB. Experimental gingivitis in man. J Periodontol. 1965;36:177-87.

16- Loos B, Claffey N, Crigger M. Effects of oral hygiene measures on clinical and microbiological parameters of periodontal disease. $\mathrm{J}$ Clin Periodontol. 1988;15:211-6.

17- McNabb H, Mombelli A, Lang NP. Supragingival cleaning 3 times a week. The microbiological effects in moderately deep pockets. J Clin Periodontol. 1992;19:348-56.

18- Mousquès T, Listgarden MA, Phillips RW. Effect of scaling and root planing on the composition of the human subgingival microbial flora. J Periodontal Res. 1980;15:144-51.

19- Mühlemann HR, Son S. Gingival sulcus bleeding-aleading symptom in initial gingivitis. Helv Odontol Acta. 1971;15:107-13.

20- Ramberg P, Sekino S, Uzel NG, Socransky SS, Lindhe J. Bacterial colonization during the novo plaque formation. J Clin Periodontol. 2003;30:990-5.

21- Sato K, Yoneyama T, Okamoto H, Dahlen G, Lindhe J. The effect of subgingival debridement on periodontal disease parameters and the subgingival microbiota. J Clin Periodontol. 1993;20:359-65.

22- Siegrist B, Kornman KS. The effect of supragingival plaque control on the composition of the subgingival microbial flora in ligatureinduced periodontitis in the monkey. J Dent Res. 1982;61:936-41.

23- Smulow JB, Turesky SS, Hill RG. The effect of supragingival plaque removal on anaerobic bacteria in deep periodontal pockets. J Am Dent Assoc. 1983;107:737-42.

24- Spolsky VW. Epidemiologia das doenças gengival e periodontal. In: Carranza FA, Newman MG. Periodontia Clínica. 8th ed. Rio de Janeiro: Guanabara Koogan; 1997. p. 65-84.

25- Van der Velden U. Influence of periodontal health on probing depth and bleeding tendency. J Clin Periodontol. 1980;7:129-39.

26- Westfelt E, Rylander H, Dahlen G, Lindhe J. The effect of supragingival plaque control on the progression of advanced periodontal disease. J Clin Periodontol. 1998;25:536-41.

27- Wikström M, Potempa J, Polanowsky A, Travis J, Renvert S. Detection of Porphyromonas gingivalis in gingival exudate by a dipeptide-enhanced trypsine-like activity. J Periodontol. 1994;65:4755. 